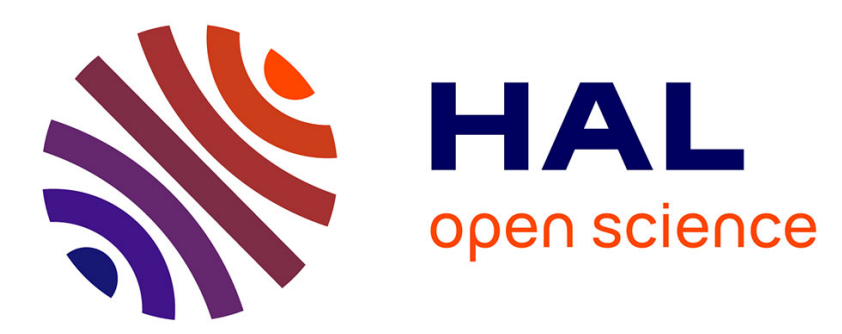

\title{
The Manufacture of High Permeability Mn-Zn Ferrites by Atmospherical Protect
}

M. Tsay, M. Tung, C. Chen, T. Liu

\section{To cite this version:}

M. Tsay, M. Tung, C. Chen, T. Liu. The Manufacture of High Permeability Mn-Zn Ferrites by Atmospherical Protect. Journal de Physique IV Proceedings, 1997, 07 (C1), pp.C1-71-C1-72. 10.1051/jp4:1997116 . jpa-00254805

\section{HAL Id: jpa-00254805 https://hal.science/jpa-00254805}

Submitted on 1 Jan 1997

HAL is a multi-disciplinary open access archive for the deposit and dissemination of scientific research documents, whether they are published or not. The documents may come from teaching and research institutions in France or abroad, or from public or private research centers.
L'archive ouverte pluridisciplinaire HAL, est destinée au dépôt et à la diffusion de documents scientifiques de niveau recherche, publiés ou non, émanant des établissements d'enseignement et de recherche français ou étrangers, des laboratoires publics ou privés. 


\title{
The Manufacture of High Permeability Mn-Zn Ferrites by Atmospherical Protect
}

\author{
M.J. Tsay, M.J. Tung, C.J. Chen and T.Y. Liu \\ Material Research Laboratories, Industrial Technology Research Institute, Dept.\#I300, Bldg. 77, 195 \\ Chung Hsing Rd., Section 4, Chutung, Hsinchu, Taiwan 310, China
}

\begin{abstract}
For the manufacture of high permeability $\mathrm{Mn}-\mathrm{Zn}$ ferrite cores, the zinc loss from the surface of sintering cores causes poor yield rate of final products. This experiment uses the atmospherical protection to reduce the evaporation of zinc. The control of the oxygen partial pressure and flow rate precisely can reduce the zinc loss about $20 \%$ to $35 \%$, but it is not enough to get a good distribution of permeability of products, i.e. the distribution of initial permeability from 12000 to 15000 per products about $14 \%$ before atmospherical control and $25 \%$ after atmospherical control, respectively. Combination with precise control and zinc vapor compensation can increase the yield rate $9 \%$ to $15 \%$. Another experiment to manufacture high permeability $\mathrm{Mn}-\mathrm{Zn}$ ferrite cores for $15000 \pm 30 \%$ in a batch type furnace(about $13 \mathrm{Kg} / \mathrm{batch}$ ), is to use a new engineering method to protect sintering core to avoid vaporizing zinc vapor, the yield rate can be rapidly increased from $25 \%$ to $75 \%$ and the effective capacity of furnace can be at least twofold. It is successful to manufacture homogeneous and high permeability of $\mathrm{Mn}-\mathrm{Zn}$ ferrites both increasing the quality of products and decreasing the operating costs.
\end{abstract}

Introduction: The high permeability Mn-Zn ferrites were developed for a long time by Dr. E Roess[1,2], but for mass production of $\mathrm{Mn}-\mathrm{Zn}$ ferrites, the homogeneily of the products is not so easy to control. The one of the paramount important reasons is the zinc loss from the outer surface of sintering cores which reduces the initial permeability, especially in the high permeability products. It is caused by the zinc vaporized of the surface of sintered cores in the reduced atmosphere, the lower oxygen partial pressure or longer annealing time, the more serious zinc vaporized[3]. It is more sensitive for smaller size high permeability $\mathrm{Mn}-\mathrm{Zn}$ ferrites than for the variation of composition. So manufacturer must be dispensed extra source to eliminate failure products, and the cost upward.

Experimental: Toroidal samples compounded with $\mathrm{Fe}_{2} \mathrm{O}_{3}, \mathrm{MnCO}_{3}, \mathrm{ZnO}$ were prepared by conventional powder metallurgy processes. Granulated powders were pressed into two size toroids, T4 $\times 2 \times 3$ (OD:4illil, ID: $2 \mathrm{~mm}, \mathrm{H}: 3 \mathrm{~mm}$ ) and T9 $\times 5 \times 3$ (OD:9mm, ID: $5 \mathrm{~mm}, \mathrm{H}: 3 \mathrm{~mm}$ ). Samples were fired in furnace, atmospheric conditions were controlled during cooling to maintain spinel phase equilibrium. In order to observe zinc vaporizing effect, $T 4 \times 2 \times 3$ samples were placed on boat shape sagas. and put into a tube furnace there were $\mathrm{ZnO}$-rich powder inside with different ratio of $\mathrm{ZnO} /$ matrix. Beside, we placed $\mathrm{T} 4$ $\times 2 \times 3$ cores into $T 9 \times 5 \times 3$ cores to coaxial sintering in the batch type furnace to compare the initial permeability distribution with the $T 4 \times 2 \times 3$ cores sintering alone.

Results and Discussion: It is well known that zinc vaporized from the outer surface of sintering cores will decrease the initial permeability [4,5]. We also discover the different position in the furnace when sintering $\mathrm{Mn}$ - $\mathrm{Zn}$ ferrite cores, the different level of zinc vaporized, so it is very difficulty to obtain homogeneous characteristics of $\mathrm{Mn}-\mathrm{Zn}$ ferrites on the manufacture.

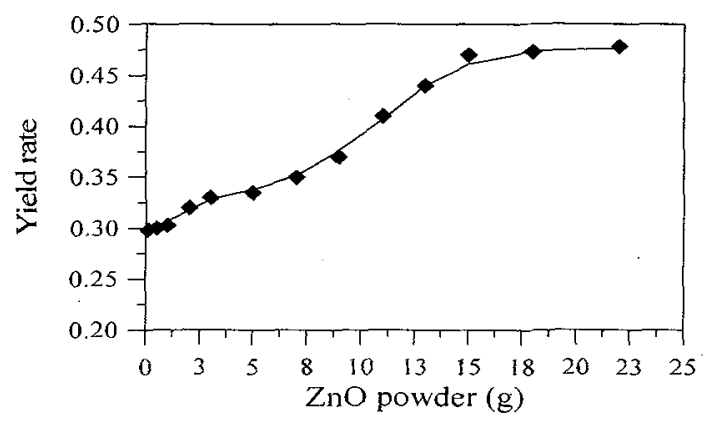

Figure 1 the relationship between the yield rate and the weight of $\mathrm{ZnO}$ powder 
Figure 1 shows the relationship between the yield rate $\left(\mu_{i}=15000 \pm 30 \%\right)$ and the weight of $\mathrm{ZnO}$ powder in the tube furnace. The actual effect of zinc loss is known, so the zinc vapor compensation were offered to reduce zinc vaporized. It is observable that zinc loss were repressed successfully by figure 1. But the yield rate increased from $30 \%$ to $47 \%$ diminutively, the reason is the bottom and surround of the cores contact with the boat shape saggars. Beside, by the restrictly of the sintering condition, the yield rate isn't increased when $\mathrm{ZnO}$ powder is beyond $18 \mathrm{gram}$. Figure $2(\mathrm{a}, \mathrm{b})$ shows the permeability distribution of T4 $\times 2$ $\times 3$ cores sintering alone compared with that coaxial sintering with $T 9 \times 5 \times 3$ cores. In figure $2 a$, the $T 4 \times 2 \times 3$ cores were strewn on the sagas arbitrarily, the permeability distribution peak is smoothly. The cores were exposed in the reduction atmosphere and reaction with saggars are the cause of the random distribution.

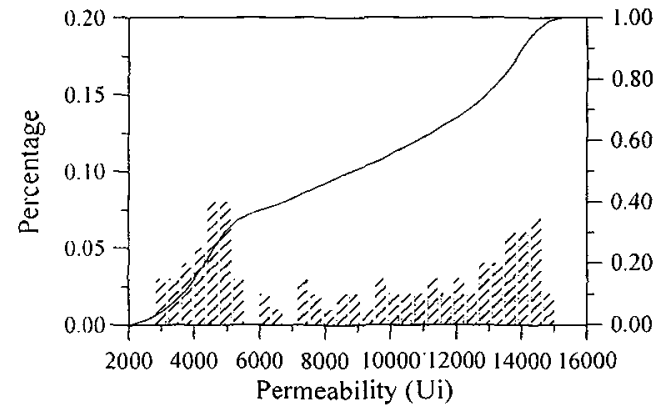

Figure $2 a$ the permeability distribution of $T 4 \times 2 \times 3$ cores sintering alone

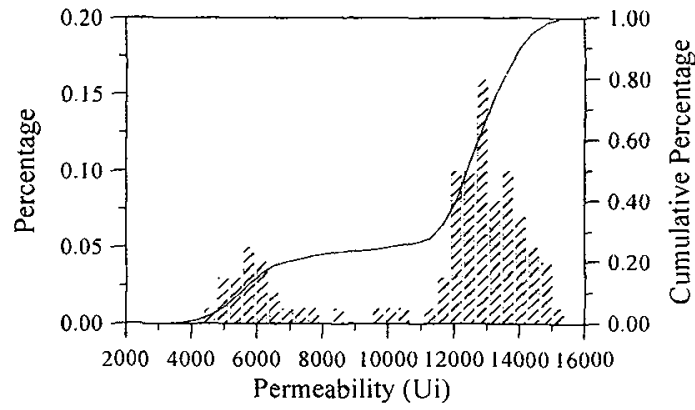

Figure $2 b$ the permeability distribution of $\mathrm{T} 4 \times 2 \times 3$ cores coaxial sintering in $\mathrm{T} 9 \times 5 \times 3$ cores

Figure $2 \mathrm{~b}$ shows the permeability distribution of $\mathrm{T} 4 \times 2 \times 3$ cores coaxial sintering in $\mathrm{T} 9 \times 5 \times 3$ cores. It is found the yield rate is increased promptly from $40 \%$ to $75 \%$, the average permeability is also upward. We can consider that the pressure of zinc vapor has achieved equilibrium to avoid the zinc vaporized during the sintering process due to the T4 $4 \times 2 \times 3$ cores in T9 $\times 5 \times$ 3 cores arrangement. But the bottom and top layers remain exposed to the reduction circumstance, so we can find the peaks at low permeability range. The yield rate of $\mathrm{T} 9 \times 5 \times 3$ cores sintering alone compared with that coaxial sintering with $\mathrm{T} 4 \times 2 \times 3$ cores isn't increased observably, but it is available to enhance the permeability.

Conclusion: By the study, it's found that despite of the decrease of the permeability due to the zinc loss during the sintering process of $\mathrm{Mn}-\mathrm{Zn}$ ferrites, it is shown that a zinc vapor compensation can raise the yield rate from $30 \%$ to $48 \%$. Else, the coaxial sintering method can efficiently increase the yield rate from $30 \%$ to $75 \%$, which leads to an improvement of both the quality of $\mathrm{Mn} \mathrm{Zn}$ ferrite cores and increase the effective capacity of furnace.

Acknowledgments: The authors would like to thank the Ministry of Economic Affairs, Republic of China, for financial support under contract number 3KF2200 to the Industrial Technology Research Institute.

\section{Reterence}

1.Smit.J. and H.P.J.Wijn, 1959, Ferrites, pp.73-75, Philips Technical Library

2.B.D.Cullity, "Introduction to Magnetic Material", 1972, CH12, pp.443-444

3.S.H.Chen, "Effect of Sintering Parameters on Zn Loss for Preparation of High Permeability MnZn Ferrites", IEEE Trans.

Mag. Vol. 28. No. 5. pp.2436-2438(1992)

4.N.J. Hellicar, Ceramic Bulletin, Vol. 61,No. 4, p.5022 (1982)

5.G. Schnitt. Z. Anorg. Allg. Chem., p.41 (1973) 